University of Wollongong

Research Online

Faculty of Business - Papers (Archive)

Faculty of Business and Law

$1-1-2014$

Secondary analysis of two environmental practice studies. Do empirical variables represent expressed theoretical constructs?

Indra Abeysekera

University of Wollongong, indraa@uow.edu.au

Follow this and additional works at: https://ro.uow.edu.au/buspapers

Part of the Business Commons

Research Online is the open access institutional repository for the University of Wollongong. For further information contact the UOW Library: research-pubs@uow.edu.au 


\title{
Secondary analysis of two environmental practice studies. Do empirical variables represent expressed theoretical constructs?
}

\begin{abstract}
Many research questions in studies on environmental practices have used variables with little regard as to whether they represent theoretical constructs. This validation is fundamental to testing and interpreting theories using variables. This study examines whether environmental disclosure, environmental performance, and economic performance are different constructs. It uses canonical correlation analysis technique, and reviews two published studies as case presentations. Analyzing the study by Al-Tuwaijri et al., the environmental disclosure variable is found to represent the disclosure construct, while the environmental performance and economic performance variables are found to represent two dimensions of the performance construct. In the Hasseldine et al. study, environmental performance is found to represent the performance construct. Results indicate that the two disclosure variables are unidimensional of the disclosure construct. These findings are supported by the main analysis and additional analysis undertaken for each study. This research demonstrates how the canonical correlation analysis technique can be used to test whether empirical variables represent expressed theoretical constructs before publishing findings. It also shows a unique way to review published studies to develop and analyze research questions not examined in the original work.
\end{abstract}

\section{Keywords}

theoretical, expressed, represent, variables, empirical, constructs, do, secondary, studies, practice, environmental, two, analysis

\section{Disciplines \\ Business}

\section{Publication Details}

Abeysekera, I. (2014). Secondary analysis of two environmental practice studies. Do empirical variables represent expressed theoretical constructs?. Journal of Cleaner Production, 15, 7-17. 


\begin{abstract}
Abeysekera, I. 2014, Do empirical variables represent expressed theoretical constructs? Secondary analysis of two environmental practice articles as case presentations, Journal of Cleaner Production, Vol. 15, pp. 7-17.
\end{abstract}

\title{
Secondary analysis of two environmental practice studies. Do empirical variables represent expressed theoretical constructs?
}

\begin{abstract}
Many research questions in studies on environmental practices have used variables with little regard as to whether they represent theoretical constructs. This validation is fundamental to testing and interpreting theories using variables. This study examines whether environmental disclosure, environmental performance, and economic performance are different constructs. It uses canonical correlation analysis technique, and reviews two published studies as case presentations. Analyzing the study by $\mathrm{Al}-$ Tuwaijri et al., the environmental disclosure variable is found to represent the disclosure construct, while the environmental performance and economic performance variables are found to represent two dimensions of the performance construct. In the Hasseldine et al. study, environmental performance is found to represent the performance construct. Results indicate that the two disclosure variables are unidimensional of the disclosure construct. These findings are supported by the main analysis and additional analysis undertaken for each study. This research demonstrates how the canonical correlation analysis technique can be used to test whether empirical variables represent expressed theoretical constructs before publishing findings. It also shows a unique way to review published studies to develop and analyze research questions not examined in the original work.
\end{abstract}

Keywords: canonical correlation analysis, disclosure, environment, performance 


\section{Introduction}

Constructs are concepts that are deliberately invented for a special scientific purpose (Kerlinger, 1973, p. 29). The variables should portray constructs in research to advance theories, because theories are statements that describe the relations among constructs within set boundaries and constraints (Bacharach, 1989).

Research shows a tendency to accept asserted variables as representing constructs without much criticism (Churchill, 1979; LeClere, 2006). For example, a study may assert that the quality of environmental disclosure is more useful to investors than quantity of environmental disclosure. Research can prove that another variable, environmental reputation, is more directly associated with the quality of environmental disclosure, than with the quantity of environmental disclosure. If the quality of environmental disclosure does not represent the disclosure construct, however, those findings, although methodologically appealing, have little meaning to advance the theoretical front.

This research undertook this secondary analysis with two objectives: first, to demonstrate a technique that can evaluate whether variables represent the theoretical constructs; and second, to understand whether variables are an accurate proxy for constructs. It did so by looking into the secondary literature on environmental practices, specifically accounting for the environment, a field that has lately received close attention from governments, society, and interest groups, due to a deep impact 
on future generations. Research in this field has contributed by examining the role of firms in accounting for the environment. Before the 1980s, environmental research explored and described ways to account for the environment (Dierkes and Preston, 1977; Mathews, 1997). During the 1980s the concern for environmental protection increased among the public, and research responded to this trend by separating accounting for society from accounting for the environment (Gray, Owen, and Maunders, 1987). Studies from this period focused on how firms measured and disclosed environmental issues in annual reports (Rockness, 1985; Wiseman, 1982). In contrast, the 1990s research examined more ways of accounting for the environment, and began to interpret findings using various theoretical frameworks. These included political economy (Arnold, 1990), legitimacy (Patten, 1992), and stakeholder theory (Roberts, 1992). The post-2000 period saw a further surge in research that responded to new issues in accounting for the environment, using theories to interpret findings. The current study chose to focus on environmental disclosure and environmental performance, which are two key areas of environmental practice research (Al-Tuwaijri, Christensen, and Hughes II., 2004; Hasseldine, Salama, and Toms, 2005).

This research selected studies by Al-Tuwaijri et al. (2004) and Hasseldine et al. (2005) as case presentations for the following three reasons. First, both studies include variables that represent environmental performance and environmental disclosure. This offers the opportunity to explore whether variables represent theoretical constructs. Second, Hasseldine et al. (2005) used two variables for disclosure, quantity and quality-weighted disclosure quantity, making it possible to examine whether the variables represent the disclosure construct. Third, Al-Tuwaijri et al. 
(2004) used variables for environmental performance and economic performance. It was thus, possible to examine whether these variables in fact represent the performance construct.

A secondary analysis can involve applying different research methods to the published data to answer new research questions. It also can involve examining the same research question as in published studies, but in a different way (McArt and McDougal, 1985). Various theories are useful for interpreting the conclusions about environmental performance, environmental disclosure, and economic performance, just as there are various ways to empirically measure them. For instance, studies have measured environmental performance as impact (Zhao, Gao, Wu, Wang, and Zhu 2014), change (Kim, Jeong, Cho, and Kim, 2014), degradation (Chen and Chu, 2011), benefits (Suk, Liu, Lee, Go, and Sudo, 2014), reputation (Hasseldine et al., 2005), or a variant of these (de Oliveira, Doll, Kurniawan, Geng, Kapshe, and Husingh, 2013). Studies have measured environmental disclosure as quantity (Al-Tuwaijri et al., 2004), volume (Gao, Heravi, and Xiao, 2005), and quality (Hasseldine et al., 2005), or a variant thereof (Lu and Abeysekra, 2014). However, previous studies have not examined in detail whether the variables used do in fact represent the construct in question, which is an important step towards building theoretical foundations.

This study used canonical correlation analysis. The types of secondary data needed to conduct the secondary analysis using this technique are the statistical mean, standard deviation, and the correlation table. The two studies under examination have the required data. Researchers have used canonical correlation analysis in studies 
published in education and psychology to examine secondary data (Sherry and Henson, 2005). The analysis of secondary data using this technique is new in the accounting field, and the current research thus contributes to understanding constructs by analyzing studies published in environmental practices. In this analysis, observed variables were first identified either as criterion or predictors to the canonical correlation analysis. It then looked into the relation that exists between two variable sets simultaneously. The analysis then produced a latent criterion that represents observed criterion variables, and a latent predictor that represents observed predictor variables. A latent variable in the canonical correlation analysis is a construct. The next step was to review the contribution that each observed variable makes to its construct. The extent to which each variable contributes to the construct helps to understand the likeness and differences of variables in relation to that construct. Similar variables make similar amounts of contribution towards explaining the construct, and unlike variables make dissimilar amounts of contribution in explaining the construct.

The two studies were separately examined because environmental disclosure and environmental performance are variables common to both studies, but measured differently. Hasseldine et al. (2005) measured the quantity of environmental disclosure using sentence count and the quality-adjusted quantity of environmental disclosure using a quality rating index that adjusted the sentence count. Al-Tuwaijri et al. (2004) used frequency count and a different quality rating index that adjusted the frequency count as a quality-weighted measure of environmental disclosure. Additionally, Al-Tuwaijri et al. (2004) conducted their study with firms in the United States, while Hasseldine et al. (2005) conducted their study with firms in the United 
Kingdom. The legal and regulatory differences influencing firm behavior also defied direct comparison. The UK annual report disclosure has a regulatory emphasis and the US annual report has a legislative emphasis (Holland and Foo, 2003). Hasseldine et al. (2005) selected large industrial firms in the UK, and Al-Tuwaijri et al. (2004) selected environmental polluting firms in the US. However, these differences did not detract from the main focus of this research, which was to examine whether the variables adequately represent the claimed constructs.

Considering the Hasseldine et al. (2005) study, this research first examined whether environmental performance (CER), disclosure quantity (SQRTES99), and qualityweighted disclosure quantity (SQRQWED99) represented different constructs. After that, another analysis was conducted to find out whether SQRTES99 and SQRQWED99 are two dimensions of the disclosure construct. The expectation was that canonical correlation analysis would reveal that disclosure and performance variables represented two constructs. It was also expected that the two disclosure variables would be found to represent two dimensions (quantity dimension and quantity-quality dimension) of the same construct.

Using the Al-Tuwaijri et al. (2004) study, the first analysis examined whether environmental performance (ENVPERF), economic performance (ECONPERF), and environmental disclosure (ENVDISC) were different constructs. After that, another analysis was conducted to find out whether ENVPERF and ECONPERF were two dimensions of the performance construct. The canonical correlation analysis was expected to reveal whether disclosure and performance variables represented two 
expressed constructs. The analysis undertaken also expected the two performance variables to represent two dimensions (environmental and economic) of the performance construct.

The remaining sections of the paper are organized as follows. The next section discusses the nature of theoretical constructs. Section 3 outlines the canonical correlation analysis technique. Section 4 presents an analysis of the study conducted by Hasseldine et al. (2005). That review was undertaken to analyze whether environmental performance and environmental disclosure are different constructs. An additional analysis tested whether the two environmental disclosure variables (quantity and quality-weighted quantity) represented the environmental disclosure construct. Section 5 presents an analysis of the study by Al-Tuwaijri et al. (2004). That review was undertaken to analyze whether environmental disclosure, environmental performance, and economic performance are separate constructs. An additional analysis tested whether the two performance variables (environmental and economic) represented the performance construct. Section 6 discusses the findings of this study and section 7 makes some concluding remarks.

\section{Expression of constructs using variables}

Constructs are abstractions that describe an observable event that cannot, however, be directly watched (MacCorquodale and Meehl, 1948). The construct becomes clear when it can break the observable event into distinct parts making it comprehensible to the community of researchers (Suddaby, 2010). The variables should portray 
constructs in research to advance theories, because theories are statements that describe the relations among constructs within set boundaries and constraints (Bacharach, 1989).

A research setting builds variables to represent a construct based on the statement proposed in the research. However, there is no guarantee that a variable represents a construct, because the observable statement of construction in research might not fully express the abstract statement of the construct. Representing a construct in research requires that researchers follow correct laws to represent the construct faithfully, so that the variable does not gain unintended meanings of the construct (MacCorquodale and Meehl, 1948).

A construct can be either single- or multi-dimensional. Understanding the meanings of a multi-dimensional construct necessitates combining multiple meanings (Law, Wong, and Mobley, 1998). For instance, understanding performance requires combining its meanings relating to environment and economics. The environmental performance and economic performance can be conceptualized under an overall abstraction of performance. Likewise, understanding disclosure needs to combine disclosures measured as quantity and quality.

Making gains on the theoretical front requires demonstrating the extent to which a variable agrees with its construct. This is becoming increasingly important because of the growing number of studies undertaken to examine environment-related events 
using variables (for example, Lu and Abeysekera, 2014; Zhao et al., 2014). Studies that have employed the multiple regression technique tend to assume that the variable expresses the construct, based on the strength of the correlation coefficient. However, a variable that is a poor proxy for its construct can show relationships within the model, but offers few or misleading clues to advance theory.

There are two ways to ensure that variables express a construct: convergent and discriminant validity tests. The convergent validity test asks whether two constructs are related to each other, while the discriminant validity test seeks to discover whether two constructs are not related to each other (Landy, 1986; Vankatraman and Grant, 1986). The multi-trait method or multi-method is a popular technique for assessing construct validity using these two categories (convergent and discriminant validity). However, this method provides only limited evidence, because it relies primarily on the correlation coefficients for its analysis, which could be influenced by the sample size (Bacharach, 1989).

The current study instead used the canonical correlation analysis technique to examine the extent to which a variable agrees with a construct. We chose two studies that met the following three conditions. First, those studies published matrix summaries (sample size, correlation table, mean, and standard deviation of variables). Second, they employed multiple regression using a continuous scale dependent variable. Third, they included environmental disclosure and environmental performance as two variables. 


\section{An overview of canonical correlation analysis}

Canonical correlation analysis extends multiple regression and correlation analyses. These last two techniques examine the linear relationship between an observed criterion variable and observed predictor variables. Canonical correlation analysis extends the analysis by looking into the relationship between two or more observed criterion variables as one set, and two or more observed predictor variables as another set. An additional advantage in using canonical correlation analysis for secondary analysis is that the researcher can choose variables as observed criterion variables and observed predictor variables. The research question being investigated can drive rearrangement of the matrix summary accordingly (Wikoff and Miller, 1991).

Canonical correlation analysis creates a latent criterion variable for the two or more observed criterion variables, and a latent predictor variable for the two or more observed predictor variables. Canonical correlation analysis develops a linear equation with the latent criterion variable and with the latent predictor variable (Sherry and Henson, 2005).

Canonical correlation analysis creates the two latent variables (criterion and predictor) to obtain the maximum explained variance between them. It creates the first canonical function by using the pairwise correlations in the observed variables. The canonical correlation analysis then analyzes the unexplained variable (that is, residual) from the first canonical function. It then obtains the maximum possible correlation between the 
two new latent variables that may result in the second canonical function (Zientek and Thompson, 2009; Wikoff and Miller, 1991).

Canonical correlation analysis can generate canonical functions that do not exceed the number of variables in the criteria set or predictor set, whichever is smaller. Each canonical function is orthogonal (that is, perfectly uncorrelated). Therefore, each canonical function can be individually interpreted. The variables included in the variable set of the canonical correlation analysis can be analyzed to support a conceptual foundation (Zientek and Thompson, 2009). For instance, variables can be tested to see whether they are dimensions of a construct (for example, quantity of disclosure and quality of disclosure), or are separate constructs (for example, disclosure and performance), using the principles in testing discriminant validity.

The canonical functions considered in interpretation are those with a reasonably statistically significant relationship in canonical models. The significant relationships are identified and analyzed using the square canonical function $\left(\mathrm{R}_{\mathrm{c}}^{2}\right)$, standardized canonical function coefficients (SCFC), and the squared structure coefficient $\left(\mathrm{R}_{\mathrm{s}}^{2}\right)$. The squared canonical function $\left(\mathrm{R}_{\mathrm{c}}^{2}\right)$ is the ratio of variance shared by the two latent variables. $\mathrm{R}_{\mathrm{c}}^{2}$ is analogous to the $\mathrm{R}^{2}$ effect of multiple regressions. Standardized canonical function coefficients (SCFC) are the standardized coefficients ("weights”) attributed to the combination of each observed variable and its respective latent variable. They are analogous to beta weights in multiple regressions. Standardized canonical function coefficients (SCFC) are useful in determining the direction of the relationship between an observed variable and its respective latent variable. A 
structure coefficient $\left(\mathrm{R}_{\mathrm{S}}\right)$ is the bivariate correlation between an observed variable and its respective latent variable. The squared structure coefficient $\left(\mathrm{R}^{2}\right)$ is the square of the structure coefficient that explains the proportion of variance an observed variable linearly shares with its construct (Afifi, Clark, and May, 2004; Sherry and Henson, 2005).

When the standardized canonical function coefficients (SCFC) and structure coefficients $\left(\mathrm{R}_{\mathrm{S}}\right)$ for the observed variables are dissimilar in the canonical correlation analysis output, the structure coefficients $\left(R_{S}\right)$ and squared structure coefficients $\left(R^{2}{ }_{s}\right)$ are used to interpret results. They then take precedence over standardized canonical function coefficients for interpretation.

No common agreement exists about the benchmark value for the $\mathrm{R}^{2} \mathrm{~s}$. The decision is usually based on the conclusions of the study to deepen the understanding of the research problem being studied. Guided by Sherry and Henson (2005), this study followed the analogy of communality coefficient in factor analysis, as an indication of the usefulness of an observed variable to the construct. This research considered $\mathrm{R}_{\mathrm{s}}^{2}$ between $0 \%$ and $45 \%$ as falling in the lower usefulness range. $\mathrm{R}^{2}$ s greater than $45 \%$ and up to $100 \%$ fell in the higher usefulness range. These ranges can be used as a guide to determine the level of usefulness observed in criterion variables examined in a study. The usefulness of an observed criterion variable is represented by the percentage of shared variance between the observed criterion variable and the latent criterion variable in each canonical function. A high usefulness (i.e., high $\mathrm{R}_{\mathrm{s}}{ }_{\mathrm{s}}$ ) of an observed criterion variable indicates that it represents the construct in question. 


\section{Study conducted by Hasseldine, Salama, and Toms (2005)}

The first part of this section outlines the findings reported by Hasseldine et al. (2005). The second and third parts present findings from the canonical correlation analysis conducted on the data published in the Hasseldine et al. study.

The second part examines whether environmental performance (CER), quantity of environmental disclosure (SQRTES99), and quality-adjusted quantity of environmental disclosure (SQRQWED99) represent different constructs. This is the main model (Table 1).

The third part describes three separate additional analyses that were undertaken as robustness testing, and that form three additional models. The first additional analysis examined whether the quantity of environmental disclosure (SQRTES99) and the quality-adjusted quantity of environmental disclosure (SQRQWED99) represented different constructs (Table 2). The second additional analysis examined whether the quantity of environmental disclosure (SQRTES99) and the environmental performance (CER) represented distinct constructs (Table 3). The third additional analysis examined whether quantity of environmental disclosure (SQRTES99, and the quality-adjusted quantity of environmental disclosure (SQRQWED99) represented different constructs (Table 4). 


\subsection{Review of Hasseldine, Salama, and Toms (2005)}

Hasseldine et al. (2005) conducted a study to compare the effects of environmental disclosures and their effect on environmental performance (measured as corporate environmental reputation) of socially and environmentally reputable firms in the UK. Using sentences that mentioned the word "environment," they measured the amount of environmental disclosure. They measured disclosure quality-adjusted disclosure quantity by adjusting the disclosure quantity with a quality indicator. Hasseldine et al. (2005) used firms' annual reports published in 1999 to obtain environmental disclosure data and related them to environmental reputation ranking published in 2000 by Management Today magazine in the UK.

The study included six predictors in each regression model. PSH was the percentage of shareholders' groups with a stake greater than 3\% of directors' shareholdings. BETA was the firm beta value. ROE was the return on equity from 1998 to 2002, inclusive, as a measure of prior economic performance. LNSIZE was annual sales in natural logarithm. R\&D was the research and development expenditure as a percent of gross revenue. DIVERS was the corporate diversification.

Hasseldine et al. (2005) conducted separate regressions for environmental disclosure measures: quantity (SQRTES99), and quality-adjusted quantity (SQRQWED99). SQRTES99 measured environmental disclosure using the number of sentences in each annual report, and SQRQWED99 adjusted the environmental disclosure measured by sentences with a five-point quality-adjusted index. Because some firms had no 
environmental disclosure in their annual reports, the quantity and quality-adjusted quantity measures were transformed into square roots. The size was measured by sales, and was transformed into natural logarithms. The researchers noted that membership in a high-profile industry group was also closely associated with greater diversification, and represented similar information content. This explained the omission of an industry variable from their correlation table. Through undertaking separate multiple regression analyses, they concluded that the quality of environmental disclosure had a stronger effect in firms' creating an environmental reputation among investors, than did the quantity of environmental disclosure.

Considering their findings, this study raised the following question for secondary analysis: Do the environmental performance (CER), the quantity of environmental disclosure (SQRTES99), and the quality-adjusted quantity of environmental disclosure (SQRQWED99) represent different constructs?

\subsection{Main Research question developed from Hasseldine et al. (2005) study}

This section empirically examines whether environmental performance, quantity of environmental disclosure, and quality-adjusted quantity of environmental disclosure are separate constructs or dimensions of a given construct. It first presents results using the main model used for this secondary analysis. Thereafter, it presents results from additional models used to test the robustness of results obtained from the main model. 
Main Research Question: Do environmental performance (CER), quantity of environmental disclosure (SQRTES99), and quality-adjusted quantity of environmental disclosure (SQRQWED99) represent different constructs?

Hasseldine et al. (2005) provided means and standard deviations for SQRTES99 and SQRQWED99. The correlation matrix comprised pairwise correlation for the eight pre-determined observed predictor variables in this study (SQRTES99, SQRQWED99, PSH, BETA, ROE, LNSIZE, R\&D, and DIVERS). The corporate environmental reputation (CER, representing environmental performance), quantity of disclosure (SQRTES99), and quality-weighted quantity of disclosure (SQRQWED99) are the three pre-determined observed criterion variables in this study (Figure 1).

Guided by Sherry and Henson (2005) and Zientek and Thompson (2009), a syntax command in SPSS was written to perform a canonical correlation analysis. In this secondary analysis, the three observed criterion variables were tested to see whether they represent different constructs through canonical correlation analysis. 
Canonical solution for firms' environmental practices (based on study by Hasseldine et al., 2005)

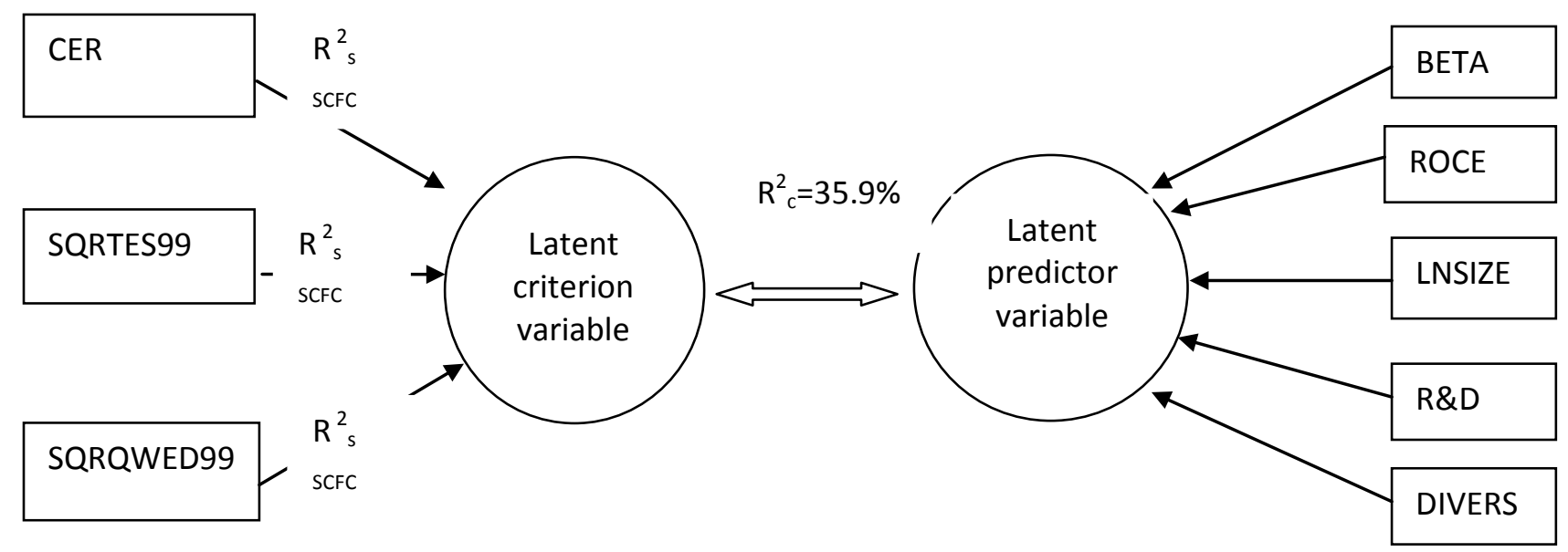

$\left(\mathrm{R}_{\mathrm{s}}^{2}\right)$ - squared structure coefficient

$\left(\mathrm{R}_{\mathrm{C}}{ }_{\mathrm{C}}\right)$ - square canonical function

(SCFC) - standardized canonical function coefficients

The canonical correlation analysis produced Pillais, Hotellings, and Wilks $\lambda$ test values. The full canonical model was significant for Pillais, Hotellings, and Wilks $\lambda$ tests. The present research used the Wilks $\lambda$ test, because it has the widest applicability in determining the overall significance of all canonical functions (Wilks $\lambda=0.641, \mathrm{~F}(12,262)=3.483, \mathrm{p}=0.001)$. However, the statistical significance does not indicate the magnitude of the relationship because it is affected by the sample size. The next step was to examine the issue of size indices to ascertain the practical significance. A Wilks $\lambda$ test of 0.641 indicated the reverse effect size; hence, the overall effect size of the model was $35.9 \%\left(R^{2}=1-0.641\right)$. 
Although three canonical functions were generated, dimension reduction analysis showed that only the first canonical function was significant. The first canonical function interpreted $31.65 \%$ of variance (Wilks $\lambda=0.641, F=3.483, p=0.001$ ).

Table 1 reports the results of the first (and only) canonical function. The standardized canonical function coefficients (SCFC) and structure coefficients for the observed variables were different. Therefore, the structure coefficients $\left(R_{S}\right)$ and squared structure coefficients $\left(\mathrm{R}_{\mathrm{s}}^{2}\right)$ became more appropriate to interpret results. The results indicated that environmental performance (CER) contributed $85.17 \%$ of the latent criterion variable of the first and only canonical function, and was the observed variable most relevant to the latent criterion variable. The quantity of disclosure (SQRTES99) contributed $43.79 \%$ and quality-adjusted quantity of disclosure (SQRQWED99) contributed 43.41\%. They made a lesser contribution to the latent criterion variable. The contribution of environmental performance (CER) to the latent variable was more than $45 \%$. The contribution of the two disclosure variables to the latent variable was less than $45 \%$. These levels of contributions indicated that performance (CER) represented a construct different from the construct the two disclosure variables (SQRTES99 and SQRQWED99) represented. 


\section{Table 1}

Canonical solution for firms' environmental practices (based on study by Hasseldine et al., 2005)

\begin{tabular}{lccc}
\hline & $\begin{array}{c}\text { Standardized } \\
\text { canonical function } \\
\text { coefficient (SCFC) }\end{array}$ & $\begin{array}{c}\text { Structure coefficient } \\
\left(\mathrm{R}_{\mathrm{S}}\right)\end{array}$ & $\begin{array}{c}\text { Squared structure } \\
\text { coefficient }\left(\mathrm{R}_{\mathrm{s}}^{2}\right)(\%)\end{array}$ \\
\hline CER & -0.796 & -0.923 & 85.17 \\
DISC & 0.161 & -0.662 & 43.79 \\
(SQRTES99) & & & 43.41 \\
DISC & -0.565 & -0.659 & \\
(SQRQWED99) & & & 35.90 \\
Squared & & & 36.83 \\
canonical function & & & 7.78 \\
$R^{2}{ }_{c}$ & -0.253 & -0.607 & 11.07 \\
PSH & -0.119 & -0.279 & 70.10 \\
BETA & -0.261 & -0.333 & 10.57 \\
ROCE & -0.641 & -0.837 & 25.61 \\
LNSIZE & -0.251 & -0.325 & \\
R\&D & -0.213 & -0.506 & \\
DIVERS & & & \\
\hline
\end{tabular}

Additional Research Questions developed from Hassaldine et al. (2005) study

Additional Research Question 1: Do the quantity of environmental disclosure (SQRTES99) and the quality-adjusted quantity of environmental disclosure (SQRQWED99) represent different constructs?

The disclosure variables quantity of disclosure (SQRTES99) and quality-adjusted quantity of disclosure (SQRQWED99) made similar contributions to the latent criterion variable. They both were below the $45 \%$ contribution benchmark. This study then conducted an additional canonical correlation analysis to examine whether they were different constructs, and the results are reported in Table 2. 
First, canonical correlation analysis dropped the quantity of disclosure (SQRTES99) from the criterion variable set in the main model. This left the environmental performance (CER) and the quality-adjusted quantity of disclosure (SQRQWED99) as the only two observed criterion variables. The results showed that only one canonical function was significant. In that canonical function, environmental performance (CER) contributed $85.74 \%$ to explain the latent criterion variable, whereas the qualityadjusted quantity of disclosure (SQRQWED99) contributed only 43.73\%. One observed variable contributed less than $45 \%$ to the latent variable, and the other observed variable contributed more than $45 \%$ to the latent variable. This result indicated that environmental performance (CER) and quality-adjusted quantity of disclosure (SQRQWED99) represented two constructs (Table 2). 
Table 2

Additional analysis of canonical solution for firms' environmental practices (based on study by Hasseldine et al., 2005), dropping DISC (SQRTES99) variable

\begin{tabular}{lccc}
\hline Criterion variables & \multicolumn{3}{c}{ CER and SQRQWED99 } \\
\cline { 2 - 4 } & $\begin{array}{c}\text { Standardized } \\
\text { canonical } \\
\text { function } \\
\text { coefficient } \\
(\text { SCFC) }\end{array}$ & $\begin{array}{c}\text { Structure } \\
\text { coefficient } \\
\left(\mathrm{R}_{\mathrm{S}}\right)\end{array}$ & $\begin{array}{c}\text { Squared } \\
\text { structure } \\
\text { coefficient } \\
\left(\mathrm{R}^{2}\right)(\%)\end{array}$ \\
\hline CER & 0.794 & 0.926 & 85.74 \\
DISC (SQRTES99) & & & \\
DISC & 0.400 & 0.661 & 43.73 \\
(SQRQWED99) & & & 31.51 \\
Squared canonical & & & 36.62 \\
function $\left(R^{2}{ }^{2}\right)$ & 0.250 & 0.605 & 7.66 \\
PSH & 0.116 & 0.277 & 11.13 \\
BETA & 0.262 & 0.334 & 69.16 \\
ROCE & 0.636 & 0.832 & 11.50 \\
LNSIZE & 0.265 & 0.339 & 25.83 \\
R\&D & 0.217 & 0.508 & \\
DIVERS & & & \\
\hline
\end{tabular}

Additional Research Question 2: Do the quantity of environmental disclosure (SQRTES99) and the environmental performance (CER) represent different constructs?

Second, canonical correlation analysis dropped the quality-adjusted quantity of disclosure (SQRQWED99) from the criterion variable set from the main model. This left the environmental performance (CER) and the quantity of disclosure (SQRTES99) as the only two observed criterion variables. The results showed that only one canonical function was significant. In that canonical function, environmental performance (CER) contributed $85.24 \%$ to the latent criterion variable, whereas the quantity of disclosure (SQRTES99) contributed only 43.38\%. One observed variable 
contributed less than $45 \%$ in explaining the latent variable. The other observed variable contributed more than $45 \%$ in explaining the latent variable. The two additional analyses indicated that environmental reputation (CER) represented a construct distinctly different from the construct that quantity of disclosure (SQRTES99) represents (Table 3).

Table 3

Additional analysis of canonical solution for firms' environmental practices (based on study by Hasseldine et al., 2005), dropping DISC (SQRQWWED99) variable

\begin{tabular}{lccc}
\hline Criterion variables & \multicolumn{3}{c}{ CER and SQRQWED99 } \\
\cline { 2 - 4 } & $\begin{array}{c}\text { Standardized } \\
\text { canonical } \\
\text { function } \\
\text { coefficient } \\
(\text { SCFC) }\end{array}$ & $\begin{array}{c}\text { Structure } \\
\text { coefficient } \\
\left(\mathrm{R}_{\mathrm{S}}\right)\end{array}$ & $\begin{array}{c}\text { Squared } \\
\text { structure } \\
\text { coefficient } \\
\left(\mathrm{R}_{\mathrm{s}}\right)^{(\%)}\end{array}$ \\
\hline CER & 0.794 & 0.923 & 85.24 \\
DISC (SQRTES99) & 0.405 & 0.659 & 43.38 \\
DISC & & & \\
(SQRQWED99) & & & \\
Squared canonical & 0.252 & 0.606 & 31.60 \\
function ( $\left.{ }^{2}{ }_{c}\right)$ & 0.118 & 0.278 & 36.74 \\
PSH & 0.262 & 0.333 & 7.72 \\
BETA & 0.640 & 0.836 & 11.12 \\
ROCE & 0.254 & 0.329 & 69.87 \\
LNSIZE & 0.214 & 0.507 & 10.79 \\
R\&D & & & 25.67 \\
DIVERS & & & \\
\hline
\end{tabular}


Additional Research Question 3: Do the quantity of environmental disclosure (SQRTES99) and the quality-adjusted quantity of environmental disclosure (SQRQWED99) represent different constructs?

Third, an additional canonical correlation analysis investigated whether the two disclosure measures were distinctly different. It dropped the environmental performance (CER) from the main model. This left the model with the quantity of disclosure (SQRTES99) and the quality-adjusted quantity of disclosure (SQRQWED99) as the only two observed criterion variables. The results indicated that the quantity of disclosure (SQRTES99) contributed 99.35\% and quality-adjusted quantity of disclosure (SQRQWED99) 99.86\%. They thus contributed similar amounts to the latent criterion variable. The contribution of both observed variables to the latent variable was greater than $45 \%$. This indicated that the quantity of disclosure (SQRTES99) and the quality-adjusted quantity of disclosure (SQRQWED99) represented the same construct. Since the quantity of disclosure (SQRTES99) and quality-adjusted quantity of disclosure (SQRQWED99) explained similar amounts of the construct, they were identical. That is, one variable could explain the construct without the help of the other. Therefore including both disclosure variables in the regression did not explain more about the construct (Table 4). 
Table 4

Additional analysis of canonical solution for firms' environmental practices (based on study by Hasseldine et al., 2005), dropping CER variable

\begin{tabular}{lccc}
\hline Criterion variables & \multicolumn{3}{c}{ CER and SQRQWED99 } \\
\cline { 2 - 4 } & $\begin{array}{c}\text { Standardized } \\
\text { canonical } \\
\text { function } \\
\text { coefficient } \\
\text { (SCFC) }\end{array}$ & $\begin{array}{c}\text { Structure } \\
\text { coefficient } \\
\left(\mathrm{R}_{\mathrm{S}}\right)\end{array}$ & $\begin{array}{c}\text { Squared } \\
\text { structure } \\
\text { coefficient } \\
\left(\mathrm{R}_{\mathrm{s}}{ }^{2}(\%)\right.\end{array}$ \\
\hline CER & & & \\
DISC (SQRTES99) & 0.316 & 0.997 & 99.35 \\
DISC & 0.686 & 0.999 & 99.86 \\
(SQRQWED99) & & & 17.90 \\
Squared canonical & 0.087 & 0.441 & 19.46 \\
function ( $\left.{ }^{2}{ }_{c}\right)$ & -0.081 & 0.085 & 0.72 \\
PSH & 0.470 & 0.525 & 27.56 \\
BETA & 0.746 & 0.849 & 72.03 \\
ROCE & 0.024 & 0.068 & 0.46 \\
LNSIZE & 0.193 & 0.452 & 20.40 \\
R\&D & & & \\
DIVERS & & & \\
\hline
\end{tabular}

\section{Study by Al-Tuwaijri, Christensen, and Hughes II (2004)}

The first part of this section outlines the findings reported by Al-Tuwaijri et al.. The second and third parts present findings from the canonical correlation analysis conducted on the published data of the study by Al-Tuwaijri et al. (2004).

The second part examines whether environmental disclosure (ENVDISC), environmental performance (ENVPERF), and economic performance (ECONPERF) are distinct constructs. This is the main model (Table 5). 
The third part describes three separate additional analyses undertaken for robustness testing. The first additional analysis examined whether environmental disclosure (ENVDISC) and environmental performance (ENVPERF) represent distinct constructs (Table 6). The second additional analysis examined whether environmental disclosure (ENVDISC) and economic performance (ECONPERF) represent distinct constructs (Table 7). The third additional analysis examined whether environmental performance (ENVPERF) and economic performance (ECONPERF) represented distinct constructs (Table 8).

\subsection{Review of Al-Tuwaijri, Christensen, and Hughes II (2004)}

The purpose of the study by Al-Tuwaijri et al. (2004) was to demonstrate how managers’ overall strategies jointly affect environmental disclosure, environmental performance, and economic performance. The authors noted that previous studies examined pairwise relationships, but did not simultaneously scrutinize the three relationships in a single, inclusive model. Al-Tuwaijri et al. (2004) used 198 of the US Standard \& Poor's 500 firms that had a minimum threshold for exposure to future environmental costs. They found these firms by searching in the IRRC Environment Profiles Directory (where a firm's pollution data were reported to the Environmental Protection Agency, or some other agency), and ensuring that the firms had sufficient environmental exposure data on Compustat, for inclusion in the study. The environmental costs considered in the study arose due to environmental pollution, considered a wasteful resource which firms were keen to minimize. 
Reviewing prior studies, Al-Tuwaijri et al. (2004) developed three questions: 1) Is there a relationship between economic performance (ECONPERF) and environmental performance (ENVPERF)? 2) Is there a relationship between environmental disclosure (ENVDISC) and environmental performance (ENVPERF)? 3) Is there a relationship between environmental disclosure (ENVDISC) and economic performance (ECONPERF)? They investigated the three questions using three simultaneous equations. The endogenous variables in the simultaneous equations were ENVDISC, ENVPERF, and ECONPERF, and each simultaneous equation had predetermined predictor variables. The empirical model used the log transformation of ENVEXP, VISIBILITY, and SIZE variables, because they were highly skewed.

Al-Tuwaijri et al. (2004) defined the variables used in their study as follows. ECONPERF was the economic performance measured as the industry-adjusted annual stock take. ENVPERF was the environmental performance measured as the percentage of total waste generated that is recycled. ENVDISCL was the environmental disclosure score obtained from content analysis of the firm's annual report. UE was the annual change in earnings per share scaled by stock price at the fiscal year-end. PREDISC was the past environmental disclosure measured as the average ENVDISCL over the preceding three years. ENVEXP was the environmental exposure measured as the natural log of toxic waste generated scaled by total revenues. ENVCON was the environmental concern measured as the primary factor obtained from factor analysis of the frequency of publishing an environmental report, the number of Environmental Protection Agency programs in which the firm participated, and whether the firm had an environmental committee. GROWTH was the market-to-book ratio of common equity. MARGIN was the profit margin (net income/net sales). VISIBILITY was the natural logarithm of the number of Wall 
Street Journal news announcements about the firm. SIZE was the natural log of the market value of common equity.

Al-Tuwaijri et al. (2004) found an endogenous relationship between ENVPERF and ENVDISC, and therefore decided to use three-stage least squares instead of ordinary least squares, and simultaneously estimate the parameters. The main findings from their analysis of the three structural equations using three-stage least squares were as follows. The results of Equation 1 suggested that ENVPERF positively and significantly relates to ECONPERF (observed criterion variable). The results of Equation 2 suggested that ECONPERF does not significantly relate to ENVPERF (observed criterion variable). The findings of Equation 3 suggested that ENVPERF is positively and significantly related to ENVDISC (observed criterion variable).

Considering the findings of their study, this secondary analysis stated its research question as: Are ENVDISC, ENVPERF, and ECONPERF distinct constructs?

\subsection{Main Research Question developed from Al-Tuwaijri et al. (2004) study}

This section empirically examines whether economic performance, environmental performance, and environmental disclosure are separate constructs or dimensions of a given construct. It first presents results using the main model used for this secondary analysis. Thereafter, it presents results from additional models used to test the robustness of results obtained from the main model. 
Main Research Question: Do the environmental disclosure (ENVDISC), environmental performance (ENVPERF), and economic performance (ECONPERF) represent distinct constructs?

This research question was examined by writing a syntax command on SPSS. A canonical correlation analysis was conducted using the seven observed predictor variables pre-determined in this study (PREDISC, ENVEXP, UE, GROWTH, MARGIN, VISIBILITY, and SIZE) as one set, and the three observed criterion variables (ENVPERF, ENVDISC, and ECONPERF) pre-determined in this study as another set (Figure 2). 
Canonical solution for firms' environmental practices (based on study by Al-Tuwaijri

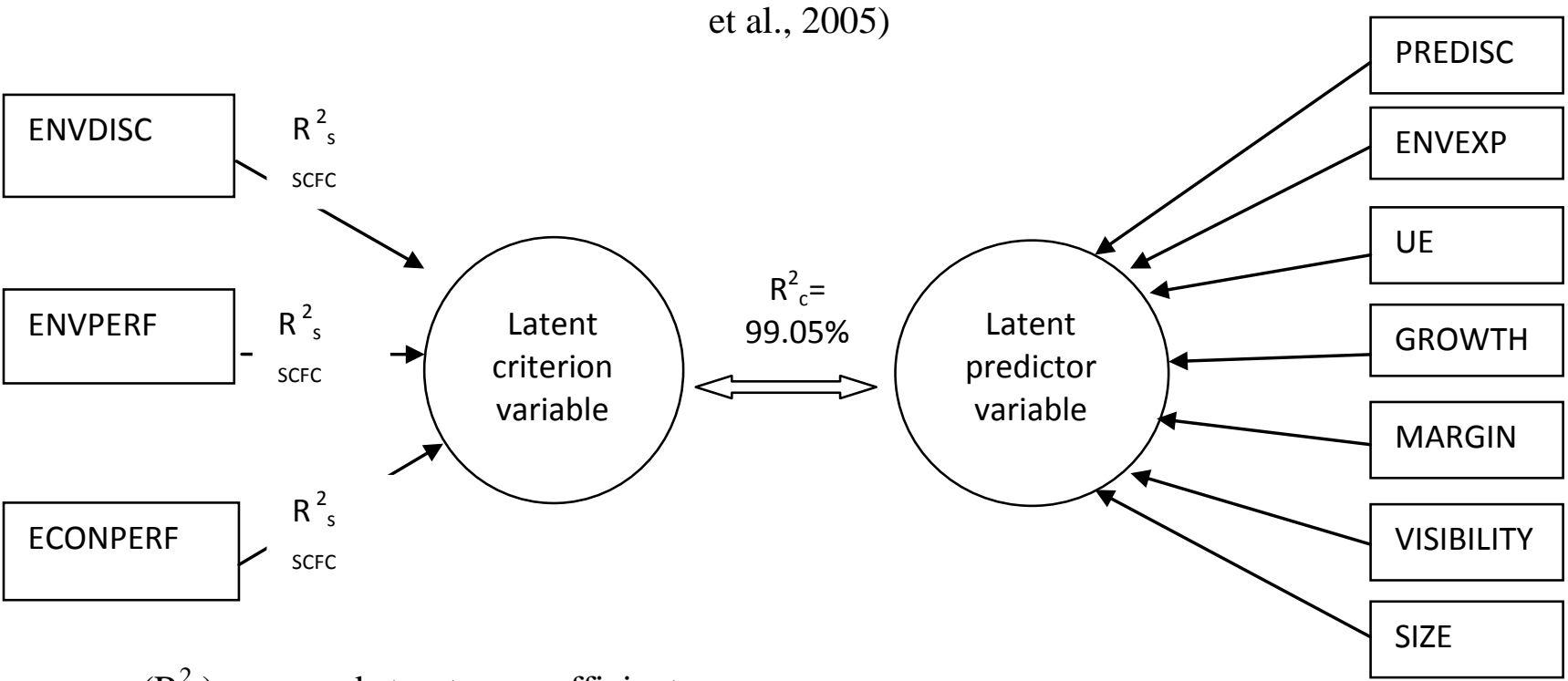

$\left(\mathrm{R}_{\mathrm{s}}^{2}\right)$ - squared structure coefficient

$\left(\mathrm{R}_{\mathrm{C}}^{2}\right)$ - square canonical function

(SCFC) - standardized canonical function coefficients

The full canonical model was significant for Pillais, Hotellings, and Wilks $\lambda$ tests. This research used the Wilks $\lambda$ test because it has the widest applicability to determine the overall significance of all canonical functions (Wilks $\lambda=0.0095, \mathrm{~F}(24,543)=$ $3.483, \mathrm{p}=0.001)$. The Wilks $\lambda$ test $(0.0095)$ result suggested the reverse effect size, and the overall effect size of the model was $99.05 \%\left(\mathrm{R}^{2}{ }_{\mathrm{c}}=1-0.0095\right)$.

Three canonical functions were generated, and the dimension reduction analysis indicated that all three were significant. The first canonical function interpreted $97.8 \%$ of variance (Wilks $\lambda=0.0095, \mathrm{~F}=90.097, \mathrm{p}=0.001$ ). The second canonical function interpreted $43.8 \%$ of variance (Wilks $\lambda=0.4411, \mathrm{~F}=13.58, \mathrm{p}=0.001$ ). The third 
canonical function interpreted $22.2 \%$ of variance (Wilks $\lambda=0.7778, \mathrm{~F}=8.999, \mathrm{p}=$ $0.001)$.

As shown in Table 5, the first canonical function indicated that environmental disclosure (ENVDISC) contributed $99.97 \%$ to the latent criterion variable. Environmental performance (ENVPERF) contributed $4.14 \%$ and economic performance (ECONPERF) contributed 11.03\%; they thus made low contributions. In the second canonical function, environmental disclosure (ENVDISC) contributed almost an insignificant $0.03 \%$. Environmental performance (ENVPERF) contributed $57.68 \%$ and economic performance (ECONPERF) contributed 59.6\%; they thus contributed similar, and much greater, amounts to the latent criterion variable. The third canonical function indicated that environmental disclosure (ENVDISC) made no contribution to the latent criterion variable. Environmental performance (ENVPERF) contributed 31.29\% and economic performance (ECONPERF) contributed 36.27\%; they thus contributed similar amounts to the third criterion variable. The three canonical functions indicated that environmental disclosure (ENVDISC) represented a construct distinct from economic performance (ECONPERF) and environmental performance (ENVPERF). 
Table 5

Canonical solution for firms’ environmental practices (based on study by Al-Tuwaijri et al., 2004)

\begin{tabular}{|c|c|c|c|c|c|c|c|c|c|}
\hline & \multicolumn{3}{|c|}{ First function } & \multicolumn{3}{|c|}{ Second function } & \multicolumn{3}{|c|}{ Third function } \\
\hline & $\begin{array}{l}\text { Standardized } \\
\text { canonical } \\
\text { function } \\
\text { coefficient } \\
\text { (SCFC) }\end{array}$ & $\begin{array}{c}\text { Structure } \\
\text { coefficient } \\
\left(R_{S}\right)\end{array}$ & $\begin{array}{c}\text { Squared } \\
\text { structure } \\
\text { coefficient } \\
\left(\mathrm{R}_{\mathrm{s}}^{2}\right)(\%)\end{array}$ & $\begin{array}{l}\text { Standardized } \\
\text { canonical } \\
\text { function } \\
\text { coefficient } \\
\text { (SCFC) }\end{array}$ & $\begin{array}{c}\text { Structure } \\
\text { coefficient } \\
\left(R_{S}\right)\end{array}$ & $\begin{array}{c}\text { Squared } \\
\text { structure } \\
\text { coefficient } \\
\left(R_{s}^{2}\right)(\%)\end{array}$ & $\begin{array}{l}\text { Standardized } \\
\text { canonical } \\
\text { function } \\
\text { coefficient } \\
\text { (SCFC) }\end{array}$ & $\begin{array}{c}\text { Structure } \\
\text { coefficient } \\
\left(\mathrm{R}_{\mathrm{S}}\right)\end{array}$ & $\begin{array}{c}\text { Squared } \\
\text { structure } \\
\text { coefficient } \\
\left(\mathrm{R}_{\mathrm{s}}^{2}\right)(\%)\end{array}$ \\
\hline ECONPERF & -0.016 & 0.203 & 4.14 & -0.635 & -0.772 & 59.60 & 0.852 & 0.602 & 36.27 \\
\hline ENVPERF & -0.007 & 0.332 & 11.03 & -0.680 & -0.759 & 57.68 & -0.869 & -0.559 & 31.29 \\
\hline ENVDISCL & 1.006 & 1.000 & 99.97 & 0.355 & -0.017 & 0.03 & 0.115 & 0.005 & 0.00 \\
\hline $\begin{array}{l}\text { Squared } \\
\text { canonical } \\
\text { function }\left(R_{c}^{2}\right)\end{array}$ & & & 97.85 & & & 43.29 & & & 22.22 \\
\hline PREDISC & 0.965 & 0.997 & 99.47 & 0.413 & 0.045 & 0.20 & 0.251 & 0.032 & 0.10 \\
\hline ENVEXP & 0.061 & 0.390 & 15.21 & -0.417 & -0.578 & 33.46 & -0.731 & -0.466 & 21.71 \\
\hline ENVCON & 0.008 & 0.460 & 21.17 & -0.287 & -0.386 & 14.89 & 0.028 & -0.175 & 3.05 \\
\hline UE & 0.012 & 0.187 & 3.48 & -0.340 & -0.540 & 29.14 & 0.679 & 0.505 & 25.46 \\
\hline GROWTH & 0.010 & 0.006 & 0.00 & -0.218 & -0.508 & 25.83 & 0.577 & 0.376 & 14.10 \\
\hline MARGIN & -0.039 & 0.077 & 0.60 & -0.386 & -0.752 & 56.59 & 0.020 & 0.054 & 0.29 \\
\hline VISIBILITY & 0.053 & 0.219 & 4.78 & -0.162 & -0.461 & 21.27 & -0.133 & -0.173 & 3.01 \\
\hline SIZE & -0.003 & 0.245 & 5.99 & 0.051 & -0.575 & 33.11 & -0.331 & -0.220 & 4.85 \\
\hline
\end{tabular}




\section{Additional Research Questions developed from Al-Tuwaijri et al. (2004) study}

In order to obtain further clarity on the distinction of constructs represented by the three observed criterion variables in the Al-Tuwaijri et al. (2004) study, this research performed three additional canonical correlation analyses.

Additional Research Question 1: Do the environmental disclosure (ENVDISC) and environmental performance (ENVPERF) represent distinct constructs?

The first additional analysis dropped economic performance (ECONPERF) as an observed criterion variable from the main model. This left environmental performance (ENVPERF) and environmental disclosure (ENVDISC) as observed criterion variables in the model. The canonical solution was significant (Wilks $\lambda=0.0139, \mathrm{~F}$ $(16,376)=175.77, \mathrm{p}=0.001)$ and explained $98.61 \%$ of the variance. The dimension reduction analysis reported that the two canonical functions were significant. The first function explained $97.84 \%$ of the variance, and the second function explained $35.78 \%$ of the variance. In the first canonical function, environmental disclosure (ENVDISC) contributed 99.99\%, and environmental performance (ENVPERF) contributed $11.18 \%$, to the latent criterion variable. In the second function, environmental performance (ENVPERF) contributed 88.82\%, but environmental disclosure (ENVDISC) barely made any contribution to the latent criterion variable (Table 4). The contribution of one observed variable to the latent variable was less than $45 \%$, while the contribution of the other observed variable to the latent variable was more than 45\%. This indicated that environmental performance (ENVPERF) and environmental disclosure (ENVDISC) are distinct constructs (Table 6). 
Table 6

Additional analysis of canonical solution, dropping ECONPERF (based on study by Al-Tuwaijri et al., 2004)

\begin{tabular}{|c|c|c|c|c|c|c|}
\hline & \multicolumn{3}{|c|}{ First function } & \multicolumn{3}{|c|}{ Second function } \\
\hline & $\begin{array}{l}\text { Standardized } \\
\text { canonical } \\
\text { function } \\
\text { coefficient } \\
\text { (SCFC) }\end{array}$ & $\begin{array}{l}\text { Structure } \\
\text { coefficient } \\
\left(R_{S}\right)\end{array}$ & $\begin{array}{c}\text { Squared } \\
\text { structure } \\
\text { coefficient } \\
\left(R_{s}^{2}\right)(\%)\end{array}$ & $\begin{array}{l}\text { Standardized } \\
\text { canonical } \\
\text { function } \\
\text { coefficient } \\
\text { (SCFC) }\end{array}$ & $\begin{array}{l}\text { Structure } \\
\text { coefficient } \\
\left(R_{S}\right)\end{array}$ & $\begin{array}{c}\text { Squared } \\
\text { structure } \\
\text { coefficient } \\
\left(\mathrm{R}_{\mathrm{s}}^{2}\right)(\%)\end{array}$ \\
\hline \multicolumn{7}{|l|}{ ECONPERF } \\
\hline ENVPERF & -0.009 & 0.334 & 11.18 & 1.064 & 0.942 & 88.82 \\
\hline ENVDISCL & 1.003 & 1.000 & 99.99 & -0.356 & 0.008 & 0.01 \\
\hline $\begin{array}{l}\text { Squared } \\
\text { canonical } \\
\text { function }\left(R_{c}^{2}\right)\end{array}$ & & & 97.84 & & & 35.78 \\
\hline PREDISC & 0.963 & 0.997 & 99.43 & -0.487 & -0.058 & 0.34 \\
\hline ENVEXP & 0.060 & 0.392 & 15.35 & 0.712 & 0.728 & 53.02 \\
\hline ENVCON & 0.011 & 0.462 & 21.34 & 0.240 & 0.421 & 17.71 \\
\hline UE & 0.018 & 0.193 & 3.72 & -0.019 & 0.238 & 5.67 \\
\hline GROWTH & 0.014 & 0.012 & 0.01 & -0.080 & 0.272 & 7.38 \\
\hline MARGIN & -0.036 & 0.083 & 0.69 & 0.331 & 0.638 & 40.70 \\
\hline VISIBLTY & 0.054 & 0.221 & 4.89 & 0.205 & 0.488 & 23.78 \\
\hline SIZE & -0.005 & 0.248 & 6.14 & 0.110 & 0.610 & 37.26 \\
\hline
\end{tabular}

Additional Research Question 2: Do the environmental disclosure (ENVDISC) and economic performance (ECONPERF) represent distinct constructs?

The second additional canonical correlation analysis dropped environmental performance (ENVPERF) from the main model, which left economic performance (ECONPERF) and environmental disclosure (ENVDISC) as observed criterion variables. The canonical solution was significant (Wilks $\lambda=0.0139, \mathrm{~F}(16,376)=$ 175.77, $\mathrm{p}=0.001$ ) and explained $98.61 \%$ of the variance. The dimension reduction analysis reported that the two canonical functions were significant. The first function 
explained $97.85 \%$ of the variance, and the second function explained $39.29 \%$ of the variance. In the first canonical function, environmental disclosure (ENVDISC) contributed 99.97\%, and environmental performance (ECONPERF) contributed very little $(4.18 \%)$ to the latent criterion variable. In the second function, economic performance (ECONPERF) contributed $95.82 \%$ to the latent criterion variable, and the contribution from environmental disclosure (ENVDISC) was insignificant $(0.03 \%)$.

These two additional analyses further confirmed that environmental disclosure (ENVDISC) represented a construct that was distinct from economic performance (ECONPERF) and environmental performance (ENVPERF) (Table 5). When the contribution of one observed variable to the latent variable was less than $45 \%$, contribution of the other observed variable to the latent variable was more than $45 \%$. This indicated to us that economic performance (ECONPERF) and environmental disclosure (ENVDISC) were distinct constructs (Table 7). 


\section{Table 7}

Additional analysis of canonical solution, dropping ENVPERF from the main canonical model (based on study by Al-Tuwaijri et al., 2004)

\begin{tabular}{|c|c|c|c|c|c|c|}
\hline & \multicolumn{3}{|c|}{ First function } & \multicolumn{3}{|c|}{ Second function } \\
\hline & $\begin{array}{l}\text { Standardized } \\
\text { canonical } \\
\text { function } \\
\text { coefficient } \\
\text { (SCFC) }\end{array}$ & $\begin{array}{l}\text { Structure } \\
\text { coefficient } \\
\left(R_{S}\right)\end{array}$ & $\begin{array}{c}\text { Squared } \\
\text { structure } \\
\text { coefficient } \\
\left(\mathrm{R}_{\mathrm{s}}^{2}\right)(\%)\end{array}$ & $\begin{array}{l}\text { Standardized } \\
\text { canonical } \\
\text { function } \\
\text { coefficient } \\
\text { (SCFC) }\end{array}$ & $\begin{array}{l}\text { Structure } \\
\text { coefficient } \\
\left(R_{S}\right)\end{array}$ & $\begin{array}{c}\text { Squared } \\
\text { structure } \\
\text { coefficient } \\
\left(\mathrm{R}_{\mathrm{s}}^{2}\right)(\%)\end{array}$ \\
\hline ECONPERF & -0.016 & 0.204 & 4.18 & 1.025 & 0.979 & 95.82 \\
\hline \multicolumn{7}{|l|}{ ENVPERF } \\
\hline ENVDISCL & 1.003 & 1.000 & 99.97 & -0.210 & 0.016 & 0.03 \\
\hline $\begin{array}{l}\text { Squared } \\
\text { canonical } \\
\text { function } \\
\left(R_{c}^{2}\right)\end{array}$ & & & 97.85 & & & 39.29 \\
\hline PREDISC & 0.963 & 0.997 & 99.43 & -0.239 & -0.025 & 0.06 \\
\hline ENVEXP & 0.063 & 0.393 & 15.42 & 0.006 & 0.276 & 7.63 \\
\hline ENVCON & 0.009 & 0.462 & 6.96 & 0.264 & 0.250 & 6.27 \\
\hline UE & 0.012 & 0.187 & 39.49 & 0.628 & 0.717 & 51.45 \\
\hline GROWTH & 0.009 & 0.007 & 22.30 & 0.472 & 0.627 & 39.30 \\
\hline MARGIN & -0.038 & 0.079 & 12.01 & 0.347 & 0.683 & 46.59 \\
\hline VISIBLTY & 0.054 & 0.220 & 0.58 & 0.076 & 0.317 & 10.06 \\
\hline SIZE & -0.003 & 0.247 & 4.27 & -0.207 & 0.394 & 15.51 \\
\hline
\end{tabular}

Additional Research Question 3: Do the environmental performance (ENVPERF) and economic performance (ECONPERF) represent distinct constructs?

As reported in Table 8, the third additional canonical correlation analysis dropped environmental disclosure (ENVDISC) from the main model. This analysis was conducted to determine whether environmental performance (ENVPERF) and economic performance (ECONPERF) were two separate constructs. The canonical solution was significant (Wilks $\lambda=0.39, \mathrm{~F}(16,376)=175.77, \mathrm{p}=0.001)$ and explained $61.03 \%$ of the variance. There were two canonical functions that were 
statistically significant in this analysis. The first function explained $49.46 \%$ of the variance, and the second canonical function explained $22.9 \%$ of the variance.

In the first canonical function, environmental performance (ENVPERF) contributed 74.6\% to the latent criterion, and economic performance (ECONPERF) contributed $56.51 \%$. Both were in the higher range of the contribution (greater than the $45 \%$ benchmark). Their contribution however substantially differed within that range.

In the second canonical function, economic performance (ECONPERF) contributed 43.49\% to the latent criterion variable, and environmental performance (ENVPERF) contributed $25.39 \%$. Both contributions were in the lower range (less than the $45 \%$ benchmark). The results of this additional model indicated that environmental performance (ENVPERF) and economic performance (ECONPERF) were not two distinct constructs. The contributions of both observed criterion variables to the latent criterion were less than $45 \%$. They were, however, vastly dissimilar within that lower range. This result indicated that environmental performance (ENVPERF) and economic performance (ECONPERF) represented the same construct, but two dimensions of the same construct. Therefore, including environmental performance (ENVPERF) and economic performance (ECONPERF) variables in a study helps to enrich the performance construct by providing information about performance from two dimensions (Table 8). 
Table 8

Additional analysis of canonical solution, dropping ENVDISC from the main canonical model (based on study by Al-Tuwaijri et al., 2004)

\begin{tabular}{|c|c|c|c|c|c|c|}
\hline & \multicolumn{3}{|c|}{ First function } & \multicolumn{3}{|c|}{ Second function } \\
\hline & $\begin{array}{l}\text { Standardized } \\
\text { canonical } \\
\text { function } \\
\text { coefficient } \\
\text { (SCFC) }\end{array}$ & $\begin{array}{l}\text { Structure } \\
\text { coefficient } \\
\left(R_{S}\right)\end{array}$ & $\begin{array}{c}\text { Squared } \\
\text { structure } \\
\text { coefficient } \\
\left(R_{s}^{2}\right)(\%)\end{array}$ & $\begin{array}{l}\text { Standardized } \\
\text { canonical } \\
\text { function } \\
\text { coefficient } \\
\text { (SCFC) }\end{array}$ & $\begin{array}{l}\text { Structure } \\
\text { coefficient } \\
\left(R_{S}\right)\end{array}$ & $\begin{array}{c}\text { Squared } \\
\text { structure } \\
\text { coefficient } \\
\left(\mathrm{R}_{\mathrm{s}}^{2}\right)(\%)\end{array}$ \\
\hline ECONPERF & 0.531 & 0.752 & 56.51 & -0.911 & -0.659 & 43.49 \\
\hline ENVPERF & 0.695 & 0.864 & 74.60 & 0.793 & 0.504 & 25.39 \\
\hline \multicolumn{7}{|l|}{ ENVDISCL } \\
\hline $\begin{array}{l}\text { Squared } \\
\text { canonical } \\
\text { function }\left(R_{c}^{2}\right)\end{array}$ & & & 49.46 & & & 22.90 \\
\hline PREDISC & 0.086 & 0.435 & 18.92 & -0.032 & 0.136 & 1.85 \\
\hline ENVEXP & 0.429 & 0.715 & 51.15 & 0.666 & 0.438 & 19.16 \\
\hline ENVCON & 0.254 & 0.566 & 0.43 & -0.066 & 0.191 & 3.65 \\
\hline UE & 0.273 & 0.540 & 50.18 & -0.708 & -0.538 & 28.95 \\
\hline GROWTH & 0.169 & 0.432 & 35.14 & -0.593 & -0.437 & 19.06 \\
\hline MARGIN & 0.319 & 0.695 & 0.64 & -0.080 & -0.145 & 2.10 \\
\hline VISIBLTY & 0.173 & 0.517 & 1.34 & 0.116 & 0.141 & 1.98 \\
\hline SIZE & -0.031 & 0.632 & 10.89 & 0.330 & 0.175 & 3.05 \\
\hline
\end{tabular}

\section{Discussion}

This secondary analysis demonstrated how canonical correlation analysis technique can be used to test whether empirical variables represent expressed theoretical constructs. It also showed a unique way of reviewing published studies to develop and analyze research questions not examined in the original study. This secondary analysis examined published data provided in the studies by Hasseldine et al. (2005) and Al-Tuwaijri et al. (2004), and framed research questions that were not investigated in those studies (Table 9). The means, standard deviations, and correlation table reported in the two studies became the data sets for this secondary analysis, and data were analyzed using canonical correlation analysis technique. 
Table 9

Findings from the canonical correlation analysis

\begin{tabular}{|c|c|c|}
\hline & Hasseldine et al. (2005) & Al-Tuwaijri et al. (2004) \\
\hline \multicolumn{3}{|l|}{ Main model } \\
\hline $\begin{array}{l}\text { Main research } \\
\text { question }\end{array}$ & $\begin{array}{l}\text { Performance and disclosure } \\
\text { represent different constructs }\end{array}$ & $\begin{array}{l}\text { Performance and disclosure } \\
\text { represent different constructs }\end{array}$ \\
\hline \multicolumn{3}{|l|}{ Additional models } \\
\hline $\begin{array}{l}\text { Additional research } \\
\text { Question } 1\end{array}$ & $\begin{array}{l}\text { CER and } \\
\text { DISC(SQRQWED99) } \\
\text { represent different constructs }\end{array}$ & $\begin{array}{l}\text { ENVPERF and ENVDISC } \\
\text { represent different constructs }\end{array}$ \\
\hline $\begin{array}{l}\text { Additional research } \\
\text { Question } 2\end{array}$ & $\begin{array}{l}\text { CER and DISC(SQRTES99) } \\
\text { represent different constructs }\end{array}$ & $\begin{array}{l}\text { ECONPERF and ENVDISC } \\
\text { represent different constructs }\end{array}$ \\
\hline $\begin{array}{l}\text { Additional research } \\
\text { Question } 3\end{array}$ & $\begin{array}{l}\text { DISC(SQRTES99) and } \\
\text { DISC(SQRQWED99) } \\
\text { represent the same dimension } \\
\text { of the same construct }\end{array}$ & $\begin{array}{l}\text { ENVPERF AND } \\
\text { ECONPERF represent two } \\
\text { dimensions of the same } \\
\text { construct }\end{array}$ \\
\hline
\end{tabular}

Using the study of Hasseldine et al. (2005), and limiting its scope to the environment, this analysis suggested that environmental performance and environmental disclosure were two distinct constructs. The two disclosure measures represented not only a single construct but also a single dimension of disclosure. The two disclosure variables were measured differently in the regression analysis in the study by Hasseldine et al., as the quantity of disclosure (SQRTES99) and quality-adjusted quantity of disclosure (SQRQWED99). These two variables provided the same information about the construct. Both variables conceptually represented the same dimension of the disclosure, and one variable was sufficient to theoretically inform 
about disclosure. This informs a principle that having additional variables in a study is methodologically acceptable, but may not add to theoretical advancement.

Using the study by Al-Tuwaijri et al. (2004), this secondary analysis investigated whether disclosure and performance were distinct constructs, and the results confirmed this distinction. The canonical correlation analysis results did not support the conclusion that environmental performance and economic performance were two distinct constructs. They were, however, two dissimilar dimensions of the same performance construct. Therefore, including these two variables is not only methodologically acceptable, but also contributes to theoretical advancement. These findings were consistent with the expected results.

Good practice should ensure that the variables sufficiently express the constructs before finalizing findings of a research study. The constructs must be carefully defined (e.g. environmental disclosure, environmental performance). Constructs should have limited scope (e.g., for the environment) and a defined context in which they are investigated (e.g. environmental performance in the context of pollution, or environmental performance in the context of reputation). Constructs that carry common speech labels without definitions, and are not limited in their application to time and scope, can acquire "surplus meaning," because such terms could be broadly interpreted (Suddaby, 2010). For example, the disclosure must be defined limiting its scope to the environment. When a construct is not sufficiently delineated, researchers may introduce definitions that are usable but that do not fit the construct. A construct 
does not sit in isolation; it is often related to other constructs, through which it gains coherence. The coherence of a construct is indicated by demonstrating its positioning among the other constructs that are under investigation or not in the study. For example, as demonstrated in this secondary analysis, performance is a multidimensional construct. Environmental performance and economic performance are two dimensions in the study by Al-Tuwaijri et al. (2004).

Scientific knowledge is built upon a theoretical basis where constructs are the building blocks of a theory. Scientific inquiry tests the theories to advance scientific knowledge. In doing so, studies should identify the constructs and how constructs are interrelated in a stated theory. For instance, Al-Tuwaijri et al. (2004) used the theory of discretionary disclosure to support their findings (Verrecchia, 1983). This theory argues that firms' discretionary disclosure has a cost. For example, that cost can lead to decreasing the stock price. Disclosing bad news can increase the cost of disclosing. Disclosing good news should have a benefit more than the cost incurred in disclosing it. Withholding news can also have a cost. The users can assume withholding news means it must be bad news, but they cannot be sure. Users make that assumption only under certain conditions specific to the firm.

Al-Tuwaijri et al. examined environmental disclosure as news reported in annual reports of firms. They found that firms performing well in environmental activities disclosed more news about those activities. Al-Tuwaijri et al. measured environmental performance as the percentage of total waste generated that is recycled. They 
empirically measured environmental disclosure as disclosure score obtained from content analysis of the firm's annual report. The disclosure score examined four aspects of environmental performance identified in Securities Exchange Commission (SEC) Form 10-K. Firms disclosing about a given environmental performance aspect received a score of 1 , otherwise zero.

In this context, it would be helpful to the reader that study explaining why the environmental disclosure construct was measured empirically combining good and bad news disclosed in the annual report. Disclosing good news about environmental performance is beneficial to the firm because investors will assess it favorably. However, disclosing bad news adds an additional cost to the firm because investors will assess it unfavorably. It would be also helpful to inform readers about the selection of four performance aspects reported in SEC Form 10-K to constitute the disclosure variable. Reporting in the SEC Form $10-\mathrm{K}$ is mandatory, and once reported in that form, the information is no longer news or discretionary disclosure. This secondary analysis points out that such a discussion helps to inform the choice of construct (for example, disclosure), the choice of variable(s) that represent the construct (for example, measured as news items), and how that selection informs testing the chosen theory (for example, theory of discretionary disclosure). Making such choices is a necessary activity in research and is important in helping to advance scientific knowledge through the testing of theories. 


\section{Conclusions}

Canonical correlation analysis can assist in conducting a post-mortem on the results before data are published, to ensure that the variables sufficiently represent the construct. Authors may usefully inform readers about how and why the variables represent the intended constructs or dimensions of the same construct representing the phenomena under investigation. For instance, studies can examine environmental performance by industries (pulp and paper, chemical) and develop environmental performance variables specific to industries. Canonical correlation analysis using matrix data in a research study can determine whether these environmental performance variables conceptually represent the same environmental performance construct and/or dimensions. Although this secondary analysis has considered two studies only as case presentations, future research can use canonical correlation analysis technique to examine a wider body of literature in search of various resolutions. For instance, a future study can examine a range of disclosure (or performance) variables that differ in measurement (this analysis examined only two: SQRTES99 and SQRQWED99) to ascertain whether they represent different disclosure (or performance) dimensions. This secondary analysis examined only the criterion variable set, and a future study can undertake a canonical correlation analysis to investigate the predictor variable set, to determine whether those variables represent the purported constructs. 


\section{References}

Afifi, A., V. A. Clark, and S. May. 2004. Computer-aided multivariate analysis (4th ed.). Boca Raton, FL: Chapman \& Hall/CRC.

Al-Tuwaijri, S. A., T. E. Christensen, and K. E. Hughes II. 2004. The relations among environmental disclosure, environmental performance, and economic performance: a simultaneous equations approach. Accounting, Organizations and Society, 29(5/6), 447-471.

Arnold, P. J. 1990. The state and political theory in corporate social disclosure research: a response to Guthrie and Parker. Advances in Public Interest Accounting, 3(2), 177-181.

Bacharach, S. B. 1989. Organizational theories: some criteria for evaluation. The Academy of Management Review, 14(4), 496-515.

Chen, M., and J-W. Chu. 2011. $\mathrm{NO}_{\mathrm{x}}$ photocatalytic degradation on active concrete road surface: from experiment to real scale application. Journal of Cleaner Production, 19, 1266-1272.

Churchill, G.A. Jr. 1979. A paradigm for developing better measures of marketing constructs. Journal of Marketing Research, 16(1), 64-73.

de Oliveira, J. A. P., C. N. H. Doll, T. A. Kurniawan, Y. Geng, M. Kapshe, and D. Huisingh. 2013. Promoting win-win situations in climate change mitigation, local environmental quality and development in Asian cities through co-benefits. Journal of Cleaner Production, 58, 1-6. 
Dierkes, M., and L. E. Preston. 1977. Corporate social accounting reporting for the physical environment: a critical review and implementation proposal. Accounting, Organizations and Society, 2(1), 3-22.

Gao, S. S., S. Heravi, and J. Z. Xiao. 2005. Determinants of corporate social and environmental reporting in Hong Kong: a research note. Accounting Forum, 29, 233 242.

Gray, R. H., D. L. Owen, and K. T. Maunders. 1987. Corporate Social Reporting: Accounting and Accountability. Hemel Hempstead: Prentice-Hall.

Hasseldine, J., A. I. Salama, and J. S. Toms. 2005. Quantity versus quality: the impact of environmental disclosures on the reputations of UK Plcs. British Accounting Review, 37(2), 231-248.

Holland, L., and Y. B. Foo. 2003. Differences in environmental reporting practices in the UK and US: the legal and regulatory context. British Accounting Review, 35(1), 1-18.

Kerlinger, F. N. 1973. Foundations of behavioral research (2nd ed.). New York: Holt, Rinehart \& Winston.

Kim, J-Y., S-J. Jeong, Y-J. Cho, and K-S. Kim. 2014. Eco-friendly manufacturing strategies for simultaneous consideration between productivity and environmental performances: a case study on a printed board manufacturing. Journal of Cleaner Production, 67, 249-257.

Landy, F. J. 1986. Stamp collecting versus science. American Psychologist, 41(11), 1183-1192. 
Law, K. S., C-S. Wong, and W. H. Mobley. 1998. Toward a taxonomy of multidimensional constructs. The Academy of Management Review, 23(4), 741755.

LeClere, M. 2006. Bankruptcy studies and ad-hoc variable selection: a canonical correlation analysis. Review of Accounting and Finance, 4, 410-422.

Lu, Y., and I. Abeysekera. 2004. Stakeholders' power, corporate characteristics, and social and environmental disclosure: evidence from China. Journal of Cleaner Production, 64, 426-436.

MacCorquodale, K., and P. E. Meehl. 1948. On a distinction between hypothetical constructs and intervening variables. Psychological Review, 55(2), 95-107.

Mathews, M. R. 1997. Twenty-five years of social and environmental accounting research: is there a silver jubilee to celebrate? Accounting, Auditing \& Accountability Journal, 10(4), 481-531.

McArt, E. W., and L. W. McDougal. 1985. Secondary data analysis: a new approach to nursing research. Journal of Nursing Scholarship, 17(2), 54-57.

Patten, D. M. 1992. Intra-industry environmental disclosures in response to the Alaskan oil spill: a note on legitimacy theory. Accounting, Organizations and Society, 17(5), 471-475.

Roberts, R. W. 1992. Determinants of corporate social responsibility disclosure: an application of stakeholder theory. Accounting, Organizations and Society, 17(6), 595-612. 
Rockness, J. W. 1985. An assessment of the relationship between US corporate environmental performance and disclosure. Journal of Business Finance \& Accounting, 12(3), 339-354.

Sherry, A., and R. Henson. 2005. Conducting and interpreting canonical correlation analysis in personality research: a user-friendly primer. Journal of Personality Assessment, 84(1), 37-48.

Suddaby, R. 2010. Editor's comments: construct clarity in theories of management and organization. The Academy of Management Review, 35(3), 346-357.

Suk, S., X. Liu, S-Y. Lee, S. Go, and K. Sudo. 2014. Affordability of energy cost increases for Korean companies due to market-based climate policies: a survey study by sector. Journal of Cleaner Production, 67, 208-219.

Venkatraman, N., and J. H. Grant. 1986. Construct management in organizational strategy research: a critique and proposal. The Academy of Management Review, 11(1), 71-87.

Verrecchia, R. E. 1983. Discretionary disclosure. Journal of Accounting and Economics, 5, 179-194.

Wikoff, R. L., and P. Miller. 1991. Canonical analysis in nursing research. Nursing Research, 40(6), 367-370.

Wiseman, J. 1982. An evaluation of environmental disclosures made in corporate annual reports. Accounting, Organizations and Society, 7(1), 53-63. 
Zientek, L. R., and B. Thompson. 2009. Matrix summaries improve research reports: secondary analyses using published literature. Educational Researcher, 38(5), 343-352.

Zhao, H-H., Q. Gao, Y-P. Wu, Y. Wang, and X-D. Zhu. 2014. What affects green consumer behavior in China? A case study from Qingdao. Journal of Cleaner Production, 63, 143-151. 